\title{
HUBUNGAN PENGETAHUAN DAN SIKAP SUAMI DENGAN PENGGUNAAN KONDOM DI DESA BUKIT MELINTANG WILAYAH KERJA PUSKESMAS KUOK TAHUN 2014
}

\author{
Fitri Handayani \\ Dosen FIK Universitas Pahlawan Tuanku Tambusai, Riau, Indonesia
}

\begin{abstract}
ABSTRAK
Jumlah penduduk yang terus meningkat merupakan masalah besar bagi negara berkembang khususnya Indonesia, dan upaya yang dilakukan pemerintah untuk menekan angka pertumbuhan penduduk tersebut direncanakan melalui program keluarga berencana (KB). Pada tahun 2013 yang menggunakan kondom di Indonesia sekitar 3,01\%, suntik sebanyak 44,04\%, pil 23, 36\%, IUD 16,78\%, MOW 3,28\%, MOP 0,66\%. Tujuan Penelitian ini adalah untuk mengetahui hubungan pengetahuan dan sikap suami dengan penggunaan kondom di Desa Bukit Melintang Wilayah Kerja Puskesmas Kuok tahun 2014. Kondom merupakan selubung atau sarung karet yang terbuat dari berbagai bahan diantaranya lateks (karet), plastic (vinil) atau bahan alami (produksi hewani) yang dipasang pada penis saat berhubungan seksual. Penelitian ini menggunakan metode analitik dengan pendekatan cross sectional yang dilakukan di Desa Bukit Melintang Wliyah Kerja Puskesmas Kuok terhadap 114 orang suami. Populasi dalam penelitian ini adalah semua pria yang sudah menikah dan memiliki keturunan 159 orang suami. Pengambilan sampel dengan teknik simple random sampling, dengan uji chi-square. Hasil penelitian menunjukkan bahwa ada hubungan bermakna antara pengetahuan suami dengan penggunaan kondom dimana $X^{2}$ hitung $(22,53)>X^{2}$ tabel $(3,841)$. Dan ada hubungan yang bermakna antara sikap suami dengan penggunaan kondom dimana $X^{2}$ hitung $=3,98>X^{2}$ tabel $=3,481$. Berdasarkan hasil penelitian ini diharapkan kepada tenaga kesehatan agar meningkatkan motivasi dan minat suami untuk menggunakan kondom sebagai kontrasepsi baik melalui penyuluhan.
\end{abstract}

Kata kunci : Pengetahuan, Penggunaan kondom, Sikap 


\section{PENDAHULUAN}

\section{A. Latar Belakang}

Jumlah penduduk yang semakin meningkat adalah salah satu masalah bagi negara-negara di dunia, khususnya negara berkembang. Indonesia berada di urutan keempat untuk negara yang memiliki penduduk terbesar, setelah Cina, India, dan Amerika Serikat (Manggiasih, 2011).

Dari hasil sensus penduduk Indonesia dari tahun ketahun selalu meningkat. Jumlah penduduk tahun 2011 sebanyak 241 juta jiwa, dan tahun 2012 jumlah penduduk Indonesia naik menjadi 257 juta jiwa, pertumbuhan penduduk Indonesia diperkirakan $1,49 \%$ pertahun (BPS, 2012).

Untuk mengatasi kenaikan jumlah penduduk di dunia sebagai salah satu program pembangunan nasional, program keluarga berencana (KB) mempunyai arti yang sangat penting dalam upaya mewujudkan manusia Indonesia sejahtera disamping programprogram pembangunan lainnya. Dalam peraturan pemerintah No.7 tahun 2005 tentang Rencana Pembangunan Jangka Menengah Nasional (RPJNM) disebut bahwa program KB Nasional merupakan rangkaian pembangunan kependudukan dan keluarga kecil berkualitas sebagai langkah penting dalam mencapai pembangunan berkelanjutan. Pembangunan ini diarahkan sebagai upaya pengendalian kuantitas penduduk melalui keluarga berencana serta pengembangan dan peningkatan kualitas penduduk melalui perwujudan keluarga kecil yang berkualitas (BKKBN, 2012).

Menurut WHO (Word

Health Organization) keluarga berencana adalah tindakan yang membantu pasangan suami istri untuk menghindari kehamilan yang tidak diinginkan, mendapatkan kelahiran yang memang sangat diinginkan, mengatur interval diantara kehamilan, mengontrol waktu saat kelahiran dalam hubungan dengan umur suami istri serta menentukan jumlah anak dalam keluarga (Suratun, dkk. 2008).

Sekarang ini banyak metode kontrasepsi yang dapt digunakan. Jenis-jenis metode kontrasepsi tersebut antara lain : metode kontrasepsi sederhana tampa alat seperti : pantang berkala, sanggama terputus, suhu basal. Kemudian yang menggunakan alat seperti : kondom, diafragma, spermisida. Metode kontrasepsi yang kedua yaitu : metode kontrasepsi hormonal seperti : suntik, pil, Intra Uterin Devices (IUD), dan implant. Yang ketiga yaitu metode kontrasepsi mantap seperti : tubektomi dan vasektomi (Hartanto, 2004).

Kondom merupakan selubung atau sarung karet yang terbuat dari berbagai bahan diantaranya lateks (karet), plastik (vinil) atau bahan alami (produksi hewani) yang dipasang pada penis saat berhubungan seksual. Kondom dipasang pada saat penis ereksi. (Sujiatini dan Setya Arum, 2012). 
Angka partisipasi pria ber KB di Negara-Negara berkembang seperti di Paskistan sebanyak 5,2\%, Bangladesh sebanyak 13,9\%, Nepal sebanyak $24 \%$, Malaysia sebanyak $16,8 \%$ dan Jepang sebanyak $80 \%$. Sedangkan Indonesia tahun 2012 sebanyak 2\%. Maka Indonesia masih menjadi Negara yang paling rendah tingkat partisipasi pria dalam ber KB (Fadila, 2012).

Berdasarkan data BKKBN, jumlah yang menggunakan kontrasepsi suntik $54,35 \%$, implant $4,88 \%$, pil $28,65 \%$, IUD $5,44 \%$, kondom 5,34\%, MOW $1,04 \%$ dan MOP 0,2\% (BKKBN, 2012). Sedangkan pada tahun 2013 yang menggunakan kondom di Indonesia sekitar 3,01\%, suntik sebanyak $44,04 \%$, pil $23,36 \%$, IUD 16,78\%, MOW 3,28\%, MOP 0,66\% (BKKBN, 2013).

Penggunaan kondom sebagai alat kontrasepsi di Provinsi Riau pada tahun 2011 adalah 33.656 orang atau 5,5\%, sedangkan pada tahun 2012 mengalami penurunan yaitu sebesar 17.307 orang atau 3,7\% (Dinkes Riau,2012). Dan pada tahun 2013 mengalami peningkatan menjadi sebesar 4,16\% (BKKBN, 2013).

Berdasarkan data yang didapatkan dari profil Dinkes Kabupaten Kampar pemakaian kondom sebagai kontrasepsi di Kabupaten Kampar pada tahun 2012 adalah 2.237 dari 69843 peserta KB aktif atau 3,20\% (Dinkes Kampar, 2012). Sedangkan pada tahun 2013 adalah 1.365 dari 93.110 peserta
$\mathrm{KB}$ aktif atau $1.46 \%$ (Dinkes Kampar, 2013).

Ada beberapa faktor yang menyebabkan rendahnya partisipasi pria dalam $\mathrm{KB}$ yang dapat dilihat dari berbagai aspek. Dari pria itu sendiri (pengetahuan, sikap dan praktek serta kebutuhan yang diinginkan), faktor lingkungan sosial, budaya, masyarakat dan keluarga/istri (Endang, 2007).

Menurut Seomarji (2008), rendahnya partisipasi pria dalam ber KB dikarenakan keterbatasan pengetahuan tentang kesehatan reproduksi serta paradigma yang berkaitan dengan budaya patriarki yang masih dianut di Indonesia dimana peran peria lebih besar dari pada wanita. Sealin itu tercipta mindset dimasyarakat bahwa penggunaan alat kontrasepsi itu adalah urusan wanita. Untuk itu penting adanya kesetaraan gender dalam mendukung keberhasilan jalannya program KB.

Sedangkan

BKKBN

menyatakan bahwa yang menyebabkan rendahnya penggunaan kondom sebagai alat kontrasepsi adalah karena rendahnya pengetahuan dan pemahaman para pria tentang kondom, sikap dan prilaku suami, sosial budaya masyarakat (Fadila, 2012).

Berdasarkan studi pendahuluan yang dilakukan di Desa Bukit Melintang melalui wawancara pada 5 orang suami yang berpendidikan 2 orang yang lulus SMA dan 3 orang yang lulus SMP, dari 5 orang tersebut yang 
mengetahui pengertian dari kondom yaitu alat kontrasepsi yang berbentuk selubung yang terbuat dari karet yang bisa untuk menunda kehamilan hanya 3 orang dan yang selebih itu mereka menganggap kondom itu sebagai lelucon. Sementara mereka juga mengetahui kerugian dari kondom yaitu menganggu saat senggama dan bisa menyebabkan alergi. Dan juga mereka mengetahui bahwa kondom hanya digunakan satu kali saja, tidak dipakai berulangulang. Namun mereka tidak mengetahui cara memakai kondom. Diantara 5 orang ini tidak ada yang menggunakan kondom karena mereka menganggap urusan berKB adalah urusan wanita (istri).

Hal ini didukung oleh penelitian terdahulu yang dilakukan oleh Elita Vasra yang berjudul "hubungan antara pengetahuan dan sikap suami dengan keikutsertaan berKB di RT 27 dan RW 45 RW 10 Kelurahan Kebun Bunga Kecamatan Suka Ramai Palembang Tahun 2009" yang mana didapatkan adanya hubungan antara pengetahuan dan sikap dalam berKB. Menggunakan uji statistic chisquare dengan batas kemaknaan $\alpha$ $=0,05$, dan hasil analisa bila $p$ value $<0,05$ artinya ada hubungan bermakna antara variabel dependen dan variabel independen, dan begitu juga sebaliknya.

\section{B. Rumusan Masalah}

Berdasarkan latar belakang masalah diatas maka rumusan masalah penelitian ini adalah "Apakah ada hubungan pengetahuan dan sikap suami dengan penggunaan kondom di Desa Bukit Melintang Wilayah Kerja Puskesmas Kuok Tahun 2014?"

\section{Tujuan Penelitian}

\section{Tujuan Umum}

Untuk mengetahui hubungan pengetahuan dan sikap suami dengan penggunaan kondom di Desa Bukit Melintang Wilayah kerja Puskesmas Kuok Tahun 2014.

\section{Tujuan khusus}

a. Untuk mengetahui distribusi frekuensi pengetahuan suami dengan penggunaan kondom di Desa Bukit Melintang Wilayah Kerja Puskesmas KuokTahun 2014.

b. Untuk mengetahui distribusi frekuensi sikap suami dengan penggunaan kondom di Desa Bukit Melintang Wilayah Kerja Puskesmas KuokTahun 2014.

c. Untuk mengetahui distribusi frekuensi penggunaan kondom di Desa Bukit Melintang Wilayah Kerja PuskesmasBangkinang Barat Tahun 2014.

d. Untuk mengetahui hubungan pengetahuan dan sikap suami dengan penggunaan alat kontrasepsi kondom di Desa Bukit Melintang Wilayah Kerja Puskesmas Kuok Tahun 2014. 


\section{METODE PENELITIAN}

A. Desain penelitian

Jenis penelitian ini adalah penelitian Analitik dengan rancangan potong lintang (cross sectional) dimana variabel indenpenden pengetahuan dan sikap suami dan variabel dependen penggunaan kondom diteliti disaat bersamaan.

\section{B. Lokasi dan Waktu penelitian}

\section{Lokasi penelitian}

Penelitian ini dilaksanakan di Desa Bukit Melintang Wilayah Kerja Puskesmas Kuok Kabupaten Kampar Tahun 2014.

\section{Waktu Penelitian}

Penelitian ini dilaksanakan pada tanggal 13 s/d 20 Juni tahun 2014.

\section{Populasi dan Sampel}

1. Populasi

Populasi pada penelitian ini adalah seluruh pria yang sudah menikah dan memiliki keturunan yang berada di Desa Bukit Melintang Wilayah Kerja Puskesmas Kuok PadaTahun 2014.

2. Sampel

Sampel pada penelitian ini yaitu sebagian pria yang sudah menikah dan memiliki keturunan yang berada di Desa Bukit Melintang Wilayah Kerja Puskesmas Kuok Tahun 2014.

a. Teknik Pengambilan Sampel Teknik pengambilan sampel dalam penelitian ini adalah menggunakan teknik simple random sampling yaitu dimana pengambilan sampel dilakukan secara acak tanpa memperhatikan strata yang ada dalam anggota populasi.

b. Besar sampel

Besar sampel dalam penelitian ini sebesar 114 orang.

\section{Hasil Penelitian}

1. Analisa Univariat

a. Karekteristik Responden

1) Umur Suami

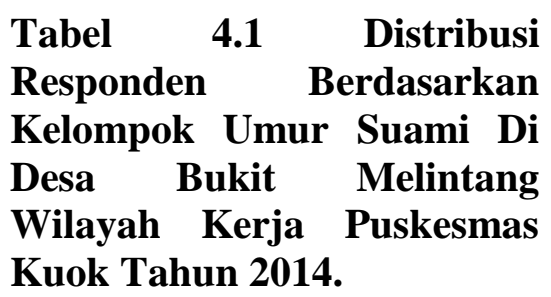

\begin{tabular}{lll}
\hline $\mathrm{N}$ Umur & $\mathrm{F}$
\end{tabular}

\begin{tabular}{|c|c|c|c|}
\hline 1 & $<20$ tahun & 4 & 3.51 \\
\hline 2 & $\begin{array}{l}20-35 \\
\text { tahun }\end{array}$ & 95 & 83,33 \\
\hline 3 & $>35$ tahun & 15 & 13,16 \\
\hline & Jumlah & 114 & 100 \\
\hline
\end{tabular}

Berdasarkan tabel 4.1 diatas dapat dilihat bahwa dari 114 orang suami di Desa Bukit Melintang Wilayah Kerja Puskesmas Kuok Tahun 2014, hampir seluruh suami berumur 20-35 tahun yaitu 95 orang $(83,33 \%)$.

2) Tingkat Pendidikan Suami 
Tabel 4.2 Distribusi

Responden Berdasarkan

Tingkat Pendidikan Suami

Di Desa Bukit Melintang

Wilayah Kerja Puskesmas Kuok Tahun 2014.

\begin{tabular}{llll}
\hline No & $\begin{array}{l}\text { Tingkat } \\
\text { Pendidikan }\end{array}$ & F & \% \\
\hline 1 & Rendah & 42 & 36,84 \\
$\mathbf{2}$ & Menengah & $\mathbf{6 1}$ & $\mathbf{5 3 , 5 1}$ \\
3 & Tinggi & 11 & 9,65 \\
\hline & Jumlah & 114 & 100 \\
\hline
\end{tabular}

Sumber:Analisa Data Primer

Berdasarkan tabel 4.2 diatas dapat dilihat bahwa dari 114 orang suami di Desa Bukit Melintang Wilayah Kerja Puskesmas Kuok Tahun 2014, sebagian suami berpendidikan menengah yaitu sebanyak 61 suami $(53,51 \%)$.

\section{3) Pekerjaan Suami}

\section{Tabel 4.3 Distribusi \\ Responden Berdasarkan Pekerjaan Suami Di Desa Bukit Melintang Wilayah Kerja Puskesmas Kuok Tahun 2014.}

\begin{tabular}{llll}
\hline N & Perkerjaan & F & $\%$ \\
o & & & \\
\hline 1 & Buruh & 7 & 6,14 \\
$\mathbf{2}$ & Petani & $\mathbf{6 7}$ & $\mathbf{5 8 , 7 7}$ \\
3 & PNS & 9 & 7,90 \\
4 & Wiraswasta & 31 & 27,19 \\
\hline & Jumlah & 11 & 100 \\
& & 4 & \\
\hline
\end{tabular}

\section{Sumber:Analisa Data Primer}

Berdasarkan tabel 4.3 diatas dapat dilihat bahwa dari
114 orang suami di Desa Bukit Melintang Wilayah Kerja Puskesmas Kuok Tahun 2014, sebagian suami bekerja sebagai petani sebanyak 67 suami $(58,77 \%)$.

\section{4) Jumlah Anak}

\begin{tabular}{lcc} 
Tabel 4.4 & \multicolumn{1}{c}{ Distribusi } \\
Responden & \multicolumn{2}{c}{ Berdasarkan } \\
Jumlah Anak & Di Desa & Bukit \\
Melintang & Wilayah & Kerja \\
Puskesmas & Kuok & Tahun \\
2014. & &
\end{tabular}

\begin{tabular}{|c|c|c|c|}
\hline No & $\begin{array}{l}\text { Jumlah } \\
\text { Anak }\end{array}$ & $\mathrm{F}$ & $\%$ \\
\hline 1 & $<2$ orang & 19 & 16,67 \\
\hline 2 & 2 orang & 14 & 12,28 \\
\hline 3 & $>2$ orang & 81 & 71,05 \\
\hline & Jumlah & 114 & 100 \\
\hline
\end{tabular}

Sumber: Analisa Data Primer

Berdasarkan tabel 4.4 diatas dapat dilihat bahwa dari 114 orang suami di Desa Bukit Melintang Wilayah Kerja Puskesmas Kuok Tahun 2014, sebagian suami yang memiliki anak $>2$ sebanyak 81 orang $(71,05 \%)$.

\section{5) Pengetahuan Suami}

\section{Tabel 4.5 Distribusi}

Responden Berdasarkan Pengetahuan Suami Di Desa Bukit Melintang Wilayah Kerja Puskesmas Kuok Tahun 2014.

\begin{tabular}{llll}
\hline $\mathrm{N}$ & Tingkat & $\mathrm{F}$ & $\%$ \\
$\mathrm{o}$ & Pengetahuan & & \\
\hline 1 & Tinggi & 8 & 7,02 \\
$\mathbf{2}$ & Rendah & $\mathbf{1 0 6}$ & $\mathbf{9 2 , 9 8}$ \\
\hline
\end{tabular}




\begin{tabular}{cc}
\hline Jumlah & $114 \quad 100$ \\
\hline Sumber:Analisa Data Primer
\end{tabular}

Berdasarkan tabel 4.5 diatas dapat dilihat bahwa dari 114 orang suami di Desa Bukit Melintang Wilayah Kerja Puskesmas Kuok Tahun 2014, hampir seluruh suami memiliki pengetahuan rendah terhadap penggunaan kondom yaitu sebanyak 106 suami (92.98\%).

\section{6) Sikap Suami}

\section{Tabel 4.6 Distribusi Responden Berdasarkan Sikap Suami Di Desa Bukit Melintang Wilayah Kerja Puskesmas Kuok Tahun 2014.}

\begin{tabular}{|c|c|c|c|}
\hline No & $\begin{array}{l}\text { Sikap } \\
\text { Suami }\end{array}$ & $\mathrm{F}$ & $\%$ \\
\hline 1 & Positif & 43 & 37,72 \\
\hline 2 & Negatif & 71 & 62,28 \\
\hline & Jumlah & 114 & 100 \\
\hline
\end{tabular}

Berdasarkan tabel 4.6 diatas dapat dilihat bahwa dari 114 orang suami di Desa Bukit Melintang Wilayah Kerja Puskesmas Kuok Tahun 2014, hampir seluruh suami memiliki sikap negatif terhadap penggunaan kondom yaitu sebanyak 71 suami (62.28\%).

\section{7) Penggunaan Kondom}

$\begin{array}{lr}\text { Tabel 4.7 } & \begin{array}{r}\text { Distribusi } \\ \text { Responden }\end{array} \\ \text { Penggunaan } & \text { Kondasarkan } \\ \text { Kendom Di } \\ \text { Desa Bukit }\end{array}$
Wilayah Kerja Puskesmas Kuok Tahun 2014.

\begin{tabular}{|c|c|c|c|}
\hline No & $\begin{array}{l}\text { Penggunaan } \\
\text { Kondom }\end{array}$ & $\mathrm{F}$ & $\%$ \\
\hline 1 & $\mathrm{Ya}$ & 5 & 4,39 \\
\hline 2 & Tidak & 109 & 95,61 \\
\hline & Jumlah & 114 & 100 \\
\hline
\end{tabular}

Berdasarkan tabel 4.7 diatas dapat dilihat bahwa dari 114 orang suami di Desa Bukit Melintang Wilayah Kerja Puskesmas Kuok Tahun 2014, hampir seluruh suami tidak menggunakan kondom yaitu sebanyak 109 suami (95.61\%).

\section{Analisa Bivariat}

a. Hubungan Pengetahuan Suami Dengan Penggunaan Kondom

Tabel $4.8 \quad$ Hubungan Pengetahuan Suami Dengan Penggunaan Kondom Di Desa Bukit Melintang Wilayah Kerja Puskesmas Kuok Tahun 2014.

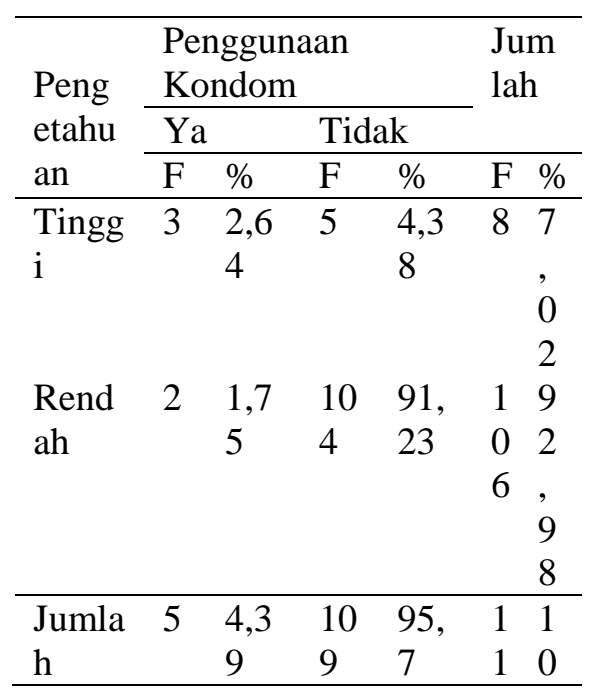


Berdasarkan uji statistik dengan menggunakan uji chisquare dengan tehnik manual dengan tingkat kepercayaan 95\% didapatkan nilai $X^{2}$ hitung $=22,53$ dengan $\mathrm{p}=$ $0,000 \quad(p<0,05)$. Ini berarti dapat diambil kesimpulan ada hubungan yang bermakna antara pengetahuan suami dengan penggunaan kondom karena $X^{2}$ hitung $(22,53)>X^{2}$ tabel $(3,841)$.

b. Hubungan Sikap

Suami Dengan
Penggunaan
Kondom

Tabel 4.9 Hubungan Sikap Suami Dengan Penggunaan Kondom Di Desa Bukit Melintang Wilayah Kerja Puskesmas Kuok Tahun 2014.

\begin{tabular}{|c|c|c|c|c|c|c|}
\hline \multirow{3}{*}{$\begin{array}{l}\text { Sik } \\
\text { ap } \\
\text { Sua } \\
\text { mi }\end{array}$} & \multicolumn{4}{|c|}{$\begin{array}{l}\text { Penggunaan } \\
\text { Kondom }\end{array}$} & \multicolumn{2}{|c|}{ Jumlah } \\
\hline & \multicolumn{2}{|c|}{ Ya } & \multicolumn{2}{|c|}{ Tidak } & & \\
\hline & $\mathrm{F}$ & $\%$ & $\mathrm{~F}$ & $\%$ & $\mathrm{~F}$ & $\%$ \\
\hline Pos & 4 & 3, & 3 & 34 & 4 & 37 \\
\hline itif & & $\begin{array}{l}5 \\
1\end{array}$ & 9 & $\begin{array}{l}2 \\
2\end{array}$ & 3 & $\begin{array}{l}7 \\
3\end{array}$ \\
\hline $\mathrm{Ne}$ & 1 & 0 , & 7 & 61 & 7 & 62 \\
\hline gati & & 8 & 0 & ,4 & 1 & ,2 \\
\hline f & & 7 & & 0 & & 7 \\
\hline $\mathrm{Ju}$ & 5 & 4, & 1 & 95 & 1 & 10 \\
\hline mla & & 3 & 0 & ,6 & 1 & 0 \\
\hline h & & 8 & 9 & 2 & 4 & \\
\hline
\end{tabular}

Berdasarkan uji statistik dengan menggunakan uji chi- square dengan tehnik manual dengan tingkat kepercayaan 95\% didapatkan Onilai $X^{2}$ hitung $=3,98>X^{2}$ tabel $=$ 3,481 dengan $\mathrm{p}=0,000$ $(\mathrm{p}<0,05)$. Artinya ada hubungan yang bermakna antara sikap suami dengan penggunaan kondom.

\section{PEMBAHASAN}

\section{A. Hubungan Pengetahuan Suami Dengan Penggunaan Kondom.}

Berdasarkan uji statistik menggunakan uji chi-square dengan tingkat kepercayaan $95 \%$ didapatkan nilai $X^{2}=22,53$ dengan $p=0,000 \quad(p<0,05)$. Ini berarti ada hubungan yang bermakna antara pengetahuan suami dengan penggunaan kondom karena $X^{2}$ hitung $(22,53)$ $>X^{2}$ tabel $(3,841)$. Berdasarkan hasil penelitian di dapatkan bahwa dari 114 orang suami di Desa Bukit Melintang Wilayah Kerja Puskesmas Kuok Tahun 2014, sebagian besar suami memiliki pengetahuan rendah terhadap penggunaan kondom yaitu sebanyak 106 suami (92.98\%).

Menurut Notoatmodjo (2010), Pengetahuan merupakan hasil "tahu" pengindraan manusia terhadap sesuatu subjek tertentu. Proses pengindraan terjadi melalui panca indra manusia, yakni indra penglihatan, pendengaran, peciuman, rasa dan melalui kulit. Pengetahuan atau kognitif merupakan dominan yangPsangat penting untuk terbentuknya tindakan seseorang. 
Pengetahuan tentang kondom merupakan salah satu pemahaman terhadap pentingnya peran serta suami dalam program $\mathrm{KB}$ dan dapat berpengaruh terhadap prilaku suami untuk berperan serta dalam ber $\mathrm{KB}$. Menurut Wawan (2010), pengetahuan merupakan dasar dari pembentukan perilaku dan perubahan perilaku seseorang, sehingga sangat penting membentuknya tindakan seseorang.

Faktor yang mempengaruhi pengetahuan seseorang yaitu pendidikan, umur, dan pekerjaan. Menurut Erfandi (2009), pendidikan akan berpengaruh pada pengetahuan responden, makin tinggi pendidikan seseorang makin mudah menerima informasi. Bila seseorang memperoleh banyak informasi maka ia cendrung mempunyai pengetahuan yang lebih luas.

Dari uraian ini dapat disimpulkan bahwa pendidikan sangat berpengaruh terhadap pengetahuan. Dalam penggunaan kondom, suami yang berpendidikan tinggi akan cendrung lebih mudah menerima informasi tentang penggunaan kondom dibandingkan suami berpendidikan rendah akan mendapatkan kesulitan untuk menerima informasi yang ada sehingga mereka kurang memahami tentang informasi yang mereka terima.

Usia adalah umur individu yang terhitung mulai saat dilahirkan sampai saat dia meninggal dunia. Semakin cukup umur, tingkat kematangan dan kekuatan seseorang akan lebih matang dalam berfikir dan berkerja.

$$
\text { Menurut Notoatmodjo }
$$
(2010) mengemukakan bahwa usia mempengaruhi daya tanggap dan pola fikir seseorang. Bertambahnya umur seseorang dapat berpengaruh pengetahuan yang diperoleh, akan tetapi pada umur-umur tertentu atau menjelang usia lanjut kemampuan menerima tau mengingat sesuatu pengetahuan akan berkurang.

Pekerjaan adalah sesuatu yang harus dilakukan terutama untuk menunjang kehidupan dan kehidupan keluarganya. Menurut Nursalam (2004) seseorang yang mempunyai pekerjaan akan mempunyai lebih banyak informasi dan pengalaman, dengan pekerjaan seseorang mempunyai waktu untuk mendapatkan informasi yang diperoleh baik dari media masa maupun dari temanya, sehingga informasi yang diperoleh semakin banyak dan pengetahuan yang dimilikinya lebih tinggi.

Menurut Gungde (2008) status pekerjaan dapat berpengaruh terhadap keikutsertaan dalam berKB karena adanya faktor pengaruh lingkungan pekerjaan yang mendorong untuk ikut dalam berKB, sehingga secara tidak langsung akan mempengaruhi status dalam pemakaian kontrasepsi.

Hal ini didukung oleh penelitian Elita Vasra yang berjudul "hubungan antara pengetahuan dan sikap suami 
dengan keikutsertaan berKB di RT 27 dan RW 45 RW 10 Kelurahan Kebun Bunga Kecamatan Suka Ramai Palembang Tahun 2009" yang didapatkan dari 54 responden dari hasil analisa uji statistik chisquare didapatkan $X^{2}$ hitung $(18,36)>X^{2}$ tabel $(3,841)$ dengan $\mathrm{p}=0,000(\mathrm{p}<0,05)$. Artinya ada hubungan antara pengetahuan suami dengan keikutsertaan dalam ber KB. Hal ini menggambarkan semakin tinggi pengetahuan suami semakin tinggi pula keikutsertaan dalam ber KB. Responden yang mempunyai pengetahuan tinggi cendrung semakin tinggi pula penggunaan kondomnya, demikian sebaliknya.

Menurut asumsi peneliti Pengetahuan yang rendah itu disebabkan kurangnya informasi yang didapatkan dan kurangnya tanggapan mereka terhadap informasi yang ada, sedangkan pendidikan dan umur mereka sangat mendukung untuk memperoleh pengetahuan yang tinggi. Disini pengetahuan sangat berperan dalam menentukan pengambilan keputusan, termasuk dalam memilih alat kontrasepsi. Jika pengetahuan seseorang tinggi maka tinggi pula pemahamannya terhadap kontrasepsi. Begitu pula dengan penggunaan kondom, semakin rendah pengetahuan suami maka semakin rendah pula penggunaan kondom, dan begitu pula sebaliknya (BKKBN,2012).

\section{B. Hubungan Sikap Suami Dengan Penggunaan Kondom}

Berdasarkan uji statistik dengan menggunakan uji chisquare dengan tingkat kepercayaan $95 \%$ didapatkan nilai $X^{2}$ hitung $=3,98>X^{2}$ tabel $=$ 3,481 dengan $\mathrm{p}=0,000(\mathrm{p}<0,05)$. Artinya ada hubungan yang bermakna antara sikap suami dengan penggunaan kondom. Berdasarkan hasil penelitian di dapatkan bahwa dari 114 orang suami di Desa Bukit Melintang Wilayah Kerja Puskesmas Kuok Tahun 2014, sebagian besar suami memiliki sikap negatif terhadap penggunaan kondom yaitu sebanyak 71 suami $(62.28 \%)$.

Menurut Wawan (2010), Sikap merupakan reaksi atau respon seseorang terhadap suatu stimulus atau objek untuk menghasilkan pengetahuan sehingga akan membentuk orang tersebut berfikir dan berusaha dalam menentukan sesuatu. Sikap seseorang dipengaruhi oleh aspek pengetahuan yang berisikan aspek positif atau aspek negatif dari sesuatu hal. Bila orang melihat lebih banyak aspek yang positif dari pada aspek negatif dan aspek positif tersebut lebih penting dari aspek negatif, maka akan tumbuh sikap yang positif terhadap hal tersebut. Sebaliknya bila melihat lebih banyak aspek negatif dari pada aspek positif, maka sikap negatiflah yang akan muncul.

Sikap merupakan reaksi atau respon yang masih tertutup dari seseorang terhadap suatu stimulus atau objek. Sikap mencerminkan kesenangan atau ketidaksenangan seseorang terhadap sesuatu. Sikap berasal dari pengalaman atau dari orang 
dekat dengan kita. Mereka dapat mengakrabkan diri kepada sesuatu atau menyebabkan kita menolaknya. Sikap berfungsi menyesuaikan dengan keadaan lingkungan, mengatur tingkah laku dan pernyataan kepribadian seseorang. Teori mengatakan tindakan seseorang dipengaruhi oleh sikapnya

(Notoatmodjo,2007).

Sikap dipengaruhi oleh Pengalaman pribadi. Untuk dapat menjadi dasar pembentukan sikap, pengalaman pribadi haruslah meninggalkan kesan yang kuat. Karena itu, sikap akan lebih mudah terbentuk apabila pengalaman pribadi tersebut terjadi. Sikap juga dipengaruhi oleh pengaruh orang lain yang dianggap penting. Pada umumnya, individu cendrung untuk memiliki sikap yang kompormis atau searah dengan sikap yang dianggap penting.

$\begin{array}{lr}\text { Pendidikan } & \text { juga } \\ \text { berpengaruh terhadap sikap } \\ \text { karena seseorang } & \text { yang } \\ \text { berpendidikan tinggi maka } & \text { man } \\ \text { mereka akan cendrung memiliki } \\ \text { sikap positif, dan sebaliknya } \\ \text { seseorang yang memiliki } \\ \text { pendidikan rendah itu akan } \\ \text { cendrung memiliki sikap yang } \\ \text { negatif pula. }\end{array}$

Menurut Sunaryo (2004) sikap menuntun prilaku seseorang sehingga seseorang akan bertindak sesuai dengan sikap yang diekspresikan. Kesadaran individu untuk menentukan tingkah laku dan prilaku yang mungkin terjadi itulah yang dimaksud dengan sikap seseorang. Begitu pula dengan penggunaan kondom. sikap negatif pada suami akan mempengaruhi terhadap penggunaan kondom, yang membuat tanggapan suami terhadap kondom itu kurang sehinnga bisa menyebabkan rendahnya penggunaan kondom.

Hal ini didukung oleh penelitian Elita Vasra yang berjudul "hubungan antara pengetahuan dan sikap suami dengan keikutsertaan berKB di RT 27 dan RW 45 RW 10 Kelurahan Kebun Bunga Kecamatan Suka Ramai Palembang Tahun 2009" yang didapatkan dari 54 responden dari hasil analisa uji statistik chisquare didapatkan $X^{2}$ hitung = $5,93>X^{2}$ tabel $=3,481$ dengan $\mathrm{p}$ $=0,000 \quad(\mathrm{p}<0,05)$. Artinya ada hubungan antara sikap suami dengan keikutsertaan dalam ber KB.

Menurut asumsi peneliti terdapat hubungan antara sikap dengan penggunaan kondom. Sikap suami itu akan mempengaruhi terhadap penggunaan kondom. suami yang memiliki sikap positif maka tanggapan terhadap penggunaan kondom jugga baik. Namun sebaliknya jika suami bersikap negatif maka buruk pula tanggapan terhadap penggunaan kondom. Sikap yang positif maupun negatif itu akan mempengaruhi tinggi atau rendahnya terhadap penggunaan kondom. sikap juga dipengaruhi oleh pengalaman, pengaruh orang lain yang dianggap penting dan juga pendidikan. Jika seseorang memiliki pengalaman yang banyak maka sikap seseorang 
akan cendrung positif. Begitu juga dengan pendidikan, orang yang berpendidikan tinggi akan cendrung memiliki sikap positif.

Sikap negatif terhadap penggunaan kondom di Desa Bukit Melintang itu disebabkan oleh kurangnya informasi yang mereka dapatkan, serta kurangnya tanggapan mereka terhadap informasi yang ada dan juga dipengaruhi oleh pengetahuan suami yang masih rendah terhadap penggunaan kondom.

\section{PENUTUP}

\section{A. Kesimpulan}

Berdasarkan hasil penelitian tentang "Hubungan Pengetahuan Dan Sikap Suami Dengan Penggunaan Kondom Di Wilayah Kerja Puskesmas Kuok Tahun 2014" dapat ditarik kesimpulan sebagai berikut:

1. Ada hubungan yang bermakna antara pengetahuan suami dengan penggunaan kondom di Desa Bukit Melintang Wilayah Kerja Puskesmas Kuok Tahun 2014.

2. Ada hubungan yang bermakna antara sikap suami dengan penggunaan kondom di Desa Bukit Melintang Wilayah Kerja Puskesmas Kuok Tahun 2014.

\section{B. Saran}

\begin{tabular}{l}
\multicolumn{2}{c}{ Berdasarkan simpulan } \\
diatas, maka \\
menyampaikan saran \\
berikut:
\end{tabular}

1. Bagi Tenaga Kesehatan
Perlu adanya penyuluhan terhadap suami tentang kondom, sehingga suami mengetahui tentang penggunaan kondom dan bisa bertanggapan positif terhadap penggunaan kondom.

2. Bagi Suami Di Desa Bukit Melintang

Perlu lebih aktif dalam mencari informasi mengenai kontrasepsi kondom, agar dapat lebih memahami dan ikut partisipasi dalam menggunakan kondom sebagai kontrasepsi.

3. Bagi Peneliti Selanjutnya Perlu dilakukan penelitian lebih lanjut dengan metode penelitian yang berbeda, variabel yang berbeda, jumlah populasi dan sampel yang lebih banyak, sehingga diperoleh hasil yang lebih baik.

\section{DAFTAR PUSTAKA}

Arum Setya, (2011). Panduan Lengkap Pelayanan $K B$ Terkini. Medical Book.

BKKBN (2011). Laporan Hasil Pelayanan Kontrasepsi. http:///www.bkbn.go.id.

Indonesia. Diperoleh tanggal 15 Maret 2014.

\section{BPS (2012). Presentase Jumlah} Penduduk. http://www.bps.co.id.

Diperoleh tanggal 20 Maret 2014. 
BKKBN (2012). Laporan Hasil Pelayanan Kontrasepsi. http:///www.bkbn.go.id. Indonesia. Diperoleh tanggal 15 maret 2014.

BKKBN (2013). Kontrasepasi Bukan Urusan Perempuan Saja. http:///www.bkbn.go.id.

Indonesia. Diperoleh tanggal 15 maret 2014.

Dinkes RI (2011). Laporan Hasil Pemantauan $K B$. http:///www.dinkes.go.id. Diperoleh tanggal 10 maret 2013.

Dinkes Kabupaten kampar, (2012). Profil Kesehatan Kabupaten Kampar. Bangkinang.

Dinkes RI (2013). Laporan Hasil Pemantauan KB. http:///www.dinkes.go.id. Diperoleh tanggal 10 maret 2013.

Fadila Dila (2012). Partisipasi Pria Dalam Pelaksanaan Keluarga Berencana Khususnya Penggunaan Alat Kontrasepsi. www.academia.edu. Diperoleh tanggal 15 maret 2013.

Endang (2007). http://pdfsearch.com diakses pada tanggal 15 Maret 2014.

Erfandi, (2009). Pengetahuan Dan Faktor Yang Mempengaruhinya.

Http://forbetterhealth.wordpres s.com. Diperoleh tanggal 30 juni 2014.
Gungde (2008). http://pdfsearch.com diakses pada tanggal 20 Juni 2014.

Hartanto Hanafi (2010). Keluarga Berencana dan Kontrasepsi. Pustaka Sinar Harapan.

Hidayat, A. Aziz, Alimul (2007). Metode Penelitian Kebidanan Teknik Analisa Data. Jakarta : Salemba Medika.

Manggiasih Bunga, (2011). Penduduk Indonesia Masuk Peringkat Ke 4 Dunia . http://www.tempo.co, jakarta. Diperoleh tanggal 20 maret 2014.

Notoadmojo Soekidjo (2010). Metodologi Penelitian Kesehatan. Jakarta : Rineka Cipta.

Notoadmojo Soekidjo (2007). Promosi Kesehatan Dan Ilmu Prilaku. Jakarta : Rineka Cipta.

Nursalam (2008). http://pdfsearch.com diakses pada tanggal 20 Juni 2014.

Uliyah Maratul, (2010). Panduan Aman dan Sehat Memilih Alat $K B$, Yugyakarta : Insania.

Puskesmas (2011). Laporan Program Keluarga Berencana. Kuok.

(2012). Laporan Program Keluarga Berencana. Kuok.

Seomarji (2008). http://pdfsearch.com diakses pada tanggal 30 Juni 2014. 
Sunaryo (2004). Psikologi Untuk Keperawatan. Jakarta : EGC

Suratun (2008). Keluarga Berencana. Yogyakarta.

STIKes TT (2014). Panduan Penulisan Karya Tulis ilmiah Mahasi. Bangkinang.

Vasra Elita, (2009). Hubungan Antara Pengetahuan dan Sikap Suami Dengan Keikutsertaan
BerKB di RT 27dan RT $45 R W$ 10 Kelurahan Kebun Bunga Kecamatan Sukaramai Palembang. www.academia.edu. Diperoleh tanggal 30 juni 2014.

Wawan (2010). Teori dan Pengukuran Pengetahuan Sikap dan Prilaku Yogyakarta : Nuha Medika. 